\title{
Wood Sector Media Promotion in Some South- East European Countries
}

\section{Medijska promocija drvnog sektora u nekim zemljama jugoistočne Europe}

\author{
Original scientific paper • Izvorni znanstveni rad \\ Received-prispjelo: 19. 4. 2012. \\ Accepted-prihvaćeno: 4. 9. 2012. \\ UDK: $630 * 79$ \\ doi:10.5552/drind.2012.1218
}

\begin{abstract}
Wood processing and furniture manufacturing is one of the key industrial sectors in South-East European countries. Based on its share in GDP, this industrial sector should be part of the national strategy plans. However, media coverage of wood processing and furniture manufacturing in Croatia, as well as in other SouthEast European countries, is far behind the promotion of other industrial sectors. This paper presents the current situation in promotional activities of wood sector in some South-East European countries media and it shows the differences between individual countries. Also, it presents some ideas on improving this situation according to media share of other highly profiled industrial sectors in some South-East European countries.
\end{abstract}

Key words: wood sector, media, media coverage, insertations, promotion investments

SAŽETAK • Prerada drva i proizvodnja namještaja pripada važnijim industrijskim granama u zemljama jugoistočne Europe. Njezin udio u bruto nacionalnom dohotku svrstava tu industrijsku granu među one koje bi trebale naći svoje mjesto u nacionalnim strateškim planovima. Međutim, medijsko praćenje prerade drva i proizvodnje namještaja u Hrvatskoj, kao i u drugim zemljama jugoistočne Europe, daleko zaostaje za promocijom nekih drugih industrijskih i ekonomskih grana i sektora. Ovaj će članak prikazati trenutačnu situaciju u promotivnim aktivnostima drvnog sektora u medijima nekih zemalja jugoistočne Europe $i$ istaknuti postojeće razlike među pojedinim zemljama. Usto će dati neke ideje kako popraviti postojeću situaciju u drvnom sektoru u odnosu prema drugim, promotivno visoko pozicioniranim industrijskim granama u pojedinim zemljama jugoistočne Europe.

Ključne riječi: drvni sektor, mediji, medijska pokrivenost, insertacije, investicije u promociju

\section{INTRODUCTION 1. UVOD}

When selecting the countries to be involved in this research, we chose 3 countries in South-East European region with a similar level of wood processing and furniture manufacturing in state economy. It was also decided to include countries of different status with respect to the European Union. Therefore Croatia, Slovenia and Serbia were included in this research. As all these countries have a very similar way of investigating media coverage of particular industrial and eco-

\footnotetext{
Authors are professor, assistant and young researcher at Faculty of Forestry, University of Zagreb, Croatia. ${ }^{2}$ Author is associated professor at Department of Wood Science and Technology, Biotechnical Faculty, University of Ljubljana, Slovenia. ${ }^{3}$ Author is assistant at Faculty of Forestry, University of Belgrade, Serbia. ${ }^{4}$ Author is employee of Ministry of Agriculture, Zagreb, Croatia. ${ }^{5}$ Author is professor at Faculty of Design and Technologies of Frniture and Interior, University of St. Ciril and Metodi, Skopje, Macedonia.

${ }^{1}$ Autori su profesor, asistentica i znanstvena novakinja Šumarskog fakulteta Sveučilišta u Zagrebu, Hrvatska. ${ }^{2}$ Autor je izvanredni profesor Biotehničkog fakulteta Sveučilišta u Ljubljani, Slovenija. ${ }^{3}$ Autorica je asistentica Šumarskog fakulteta Sveučilišta u Beogradu, Srbija. ${ }^{4}$ Autorica je zaposlenica Ministarstva poljoprivrede, Zagreb, Hrvatska. ${ }^{5}$ Autorica je profesorica Fakulteta dizajna i tehnologije namještaja i interijera, Sveučilište sv. Ćirila i Metoda, Skopje, Makedonija.
} 
nomic sectors within their countries, they could be easily compared.

The Republic of Croatia is located in South-East Europe with a total area of more than 56 thousand $\mathrm{km}^{2}$ and with the population of 4.5 mil people. In Croatia wood represents a significant raw material. The share of wood processing and furniture manufacturing in the Croatian GDP was about $2 \%$ in 2007. The annual wood consumption in Croatia is more than $3.4 \mathrm{mil} \mathrm{m}^{3}$ and in the year 2007, the revenues were over 1 billion Euros with more than 25 thousand employees. (Source: Statistical Yearbook of Croatia)

Industrial production indexes show significant decrease from 2007 to 2010 . The same goes for wood processing and furniture manufacturing, since these industrial sectors are the first to respond to any crisis, especially a global one. The main reason for this is the fact that wood processing and furniture manufacturing in Croatia are highly export-oriented. So, any disturbances in the global or European market have a significant influence on Croatian wood processing and furniture manufacturing (Jelačić, 2010).

The situation with employment is almost the same. The total number of employees in wood processing and furniture manufacturing decreased from 25,000 in 2007 (which was $9.8 \%$ of all employees in the industrial sector, and $1.67 \%$ of all employees in Croatia) to 21,000 in 2009 (9\% in the industrial sector, i.e. $1.41 \%$ of all employees). (Source: Statistical Yearbook of Croatia).

Economic recession has strongly influenced the operation of companies in the last several years. Its influence can be seen in all business fields, and hence also in the promotion activities of wood processing and furniture companies. At the moment, Croatia is in the process of ratification of agreement and preparing to become part of the European Union in 2013.

The Republic of Slovenia is located west of Croatia with a total area of more than 20 thousand $\mathrm{km}^{2}$ and with the population of 2 mil people. The share of wood processing and furniture manufacturing in the Slovenian GDP was about $1.5 \%$ in 2007. In the year 2007, the revenues were over 1.5 billion Euros with more than 22.5 thousand employees.

Industrial production indexes also show significant decrease from 2007 to 2010 . The total revenues decreased from 1.5 billion Euros in 2007 to 0.75 billion Euros. The total number of employees in wood processing and furniture manufacturing decreased from 22,500 in 2007 to 17.000 in 2010 and to 15,500 in 2011. Slovenia is a member of the European Union. (Source: Statistical Yearbook of Slovenia).

The Republic of Serbia is located east of Croatia with a total area of 88 thousand $\mathrm{km}^{2}$ and with the population of 7.2 mil people. The global economic crisis affected badly wood processing and furniture manufacturing in Serbia, so the number of employed people in that industrial sector decreased to 29,300 in 2010, which was $1.63 \%$ of all employed persons in Serbia. Serbia has just started the negotiation process with the European Union. (Source: University of Belgrade, Fa- culty of Forestry, Center for Marketing and Economics of Wood Industry).

\section{MATERIAL AND METHODS} 2. MATERIJAL I METODE

According to EFFIE index, 400 billion USD per year is spent on advertising and promotional activities in the world. That amount is increasing each year by $5 \%$ at least (Žujo, 2011).

Large amount of that money is invested into advertising and promotional activities on TV and printed media (newspapers, journals, magazines, etc.) (StasiakBetlejewska and Borkowski, 2007).

In South-East Europe most of the adverts appear on TV, radio and in printed media, although other ways of promotion, such as billboards or brochures and flyers, cover a significant share of the market. At the moment, the most successful promotions are those that cover several different ways of marketing, including social networks, such as Facebook (Žujo, 2011).

This paper focuses on promotional activities on $\mathrm{TV}$ and in printed media monitored by official agencies for monitoring the promotion in the key media in Croatia, Slovenia and Serbia.

AGB Nielsen is the agency that monitors insertations of adverts on national TV channels (6 national TV channels) and Gross Rating Point (GRP) index of these TV channels. Insertation is the number of broadcastings of a particular advert on a TV channel.

IPSOS is the agency that monitors adverts in printed media and on the radio. Since they have just started monitoring radio stations, the data only covers printed media. The available data will be presented through financial investments in promotion in different printed media.

The research period was from 2006 to 2011, and it covered the years of good economic conditions, the years of global recession and the years of new growth and development after the crisis.

To compare the share of the total number of insertations and the share of the total investments in promotion among Croatia, Slovenia and Serbia, the Analysis of Variance was used, popularly known as the ANOVA test. When using the ANOVA procedure, it is assumed that the data from each group follow a normal distribution and that the groups to be compared have homogeneous variances. If the variances are not all equal, the Kruskal-Wallis test (the nonparametric equivalent of the ANOVA test) should be used. Tukey HSD post hoc test was used to determine the significant difference, if any, in the ANOVA (Troendle, 1995). All analyzes were performed using the statistical package Statistics 7.1 (StatSoft Inc., 2006).

\section{RESEARCH RESULTS}

\section{REZULTATI ISTRAŽIVANJA}

Insertation is the number that shows how many times certain advert or group of adverts from a certain sector was broadcasted on a national TV channels. 
Table 1 Total number of TV insertations in individual countries for the period 2006-2010

Tablica 1. Ukupni broj emitiranja na TV-u u pojedinoj zemlji u razdoblju 2006-2010.

\begin{tabular}{|l|c|c|c|c|r|r|}
\hline Country / Država & $\mathbf{2 0 0 6}$ & $\mathbf{2 0 0 7}$ & $\mathbf{2 0 0 8}$ & $\mathbf{2 0 0 9}$ & $\mathbf{2 0 1 0}$ & $\mathbf{2 0 1 1}$ \\
\hline Croatia / Hrvatska & 242843 & 277126 & 336999 & 301928 & 342407 & 440357 \\
\hline Slovenia / Slovenija & 369338 & 375098 & 441295 & 471661 & 645432 & 642589 \\
\hline Serbia / Srbija & 606482 & 823373 & 882507 & 955407 & 1111448 & 1440619 \\
\hline
\end{tabular}

Table 1 shows the total number of insertations for the period 2006-2011 in Croatia, Slovenia and Serbia.

As shown in Table 1, the total number of insertations in Slovenia and Serbia show constant growth year after year, while in Croatia the total number of insertations decreased in the year after the financial crisis started in Croatia. Afterwards, it showed growth again. It is interesting to observe that the total number of insertations in Croatia is much less than in Slovenia, and even the Total Individual Universe (number of viewers) in Croatia is more than twice the Total Individual Universe in Slovenia (4.161.532 spectators in Croatia and $1.927 .657 \mathrm{spec}-$ tators in Slovenia). It is even more interesting since the number of national TV channels included in the research was 6 in Croatia, 5 in Slovenia and 19 in Serbia.

Table 2 presents the share of the furniture, household appliances and household accessories sector in the total number of insertations.

As shown above, the share of furniture TV promotion is much higher in Serbia than in Croatia and Slovenia. However, these shares have different trends in individual countries. In Croatia, this share was growing until 2008, then it was decreasing until 2010, and in 2007 and 2011 it was almost the same. In Slovenia, it rapidly decreased in 2008, it starting growing again in 2010 and in 2011 it was at the level of $0.29 \%$. In Serbia, it was constantly decreasing and dropped from $1.60 \%$ in 2007 to $0.67 \%$ in 2011 .

The following figures show the share of several sectors most often advertised on TV and of furniture, household appliances and accessories sector (Figures 1 to 3), and then of furniture sector in particular (Figures 5 to 7).

According to Figure 4, Kruskal-Wallis test shows that there is a significant difference between the total number of insertations and that the difference is caused by data from Serbia.

Table 2 and Figures 1 to 3 clearly show that the sector of furniture, household appliances and accessories did not have the position it deserved on TV channels. This especially applies to Croatia and Slovenia, since the share of this sector in TV promotion was from $0.20 \%$ in Slovenia for 2009 to $0.74 \%$ in Croatia for the same year. The situation in Serbia is a little bit better, since the share of furniture, household appliances

Table 2 Share of furniture, household appliances and household accessories sector in TV promotion for individual countries in the period 2006-2011 (in \%)

Tablica 2. Udio sektora namještaja, kućnih uređaja i opreme u TV promociji za pojedinu zemlju u razdoblju 2006-2011. (u \%)

\begin{tabular}{|l|c|c|c|c|c|c|}
\hline Country / Država & $\mathbf{2 0 0 6}$ & $\mathbf{2 0 0 7}$ & $\mathbf{2 0 0 8}$ & $\mathbf{2 0 0 9}$ & $\mathbf{2 0 1 0}$ & $\mathbf{2 0 1 1}$ \\
\hline Croatia / Hrvatska & 0.57 & 0.51 & 0.65 & 0.74 & 0.46 & 0.50 \\
\hline Slovenia / Slovenija & 0.43 & 0.53 & 0.25 & 0.20 & 0.30 \\
\hline Serbia / Srbija & 1.59 & 1.60 & 1.63 & 1.06 & 0.29 \\
\hline
\end{tabular}

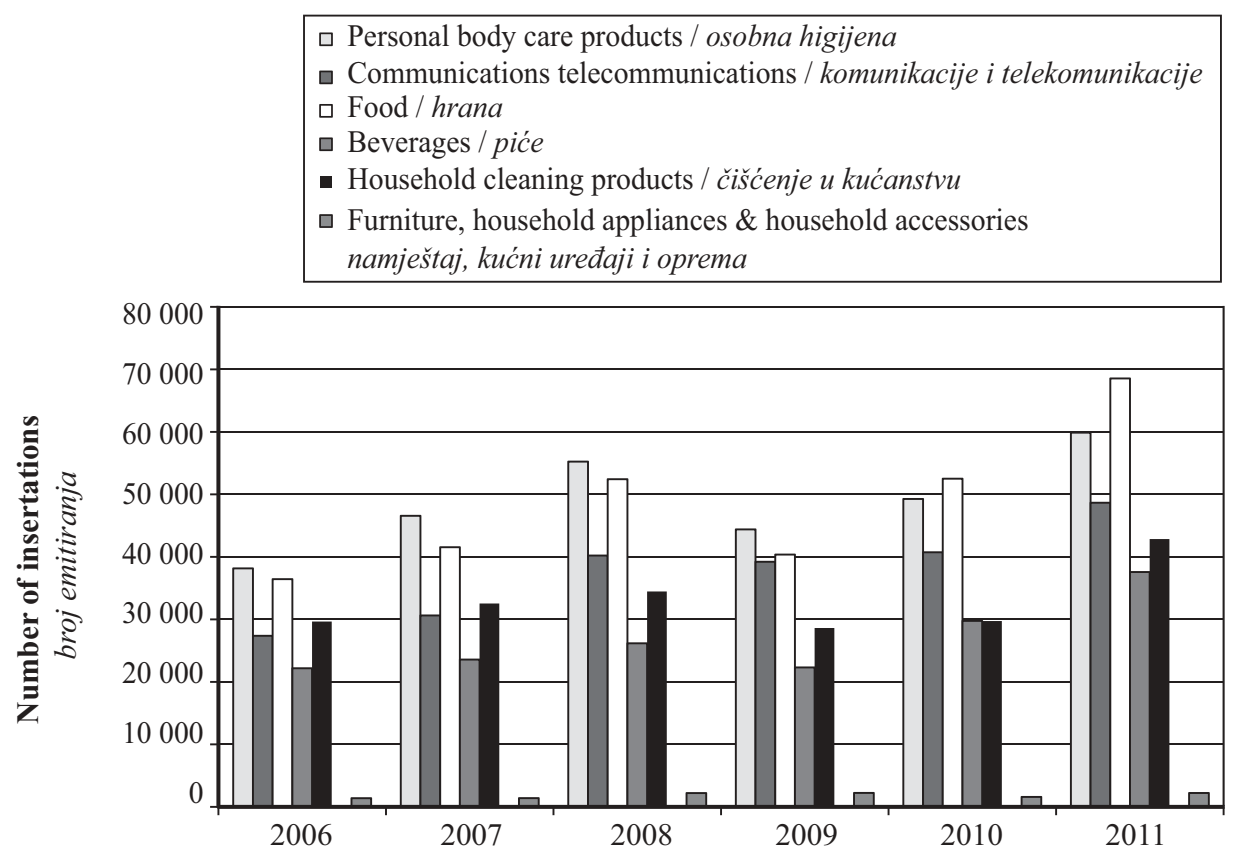

Figure 1 Number of insertations for specific sectors in Croatia for the period 2006-2011

Slika 1. Broj emitiranja za pojedine sektore u Hrvatskoj u razdoblju 2006-2011. 

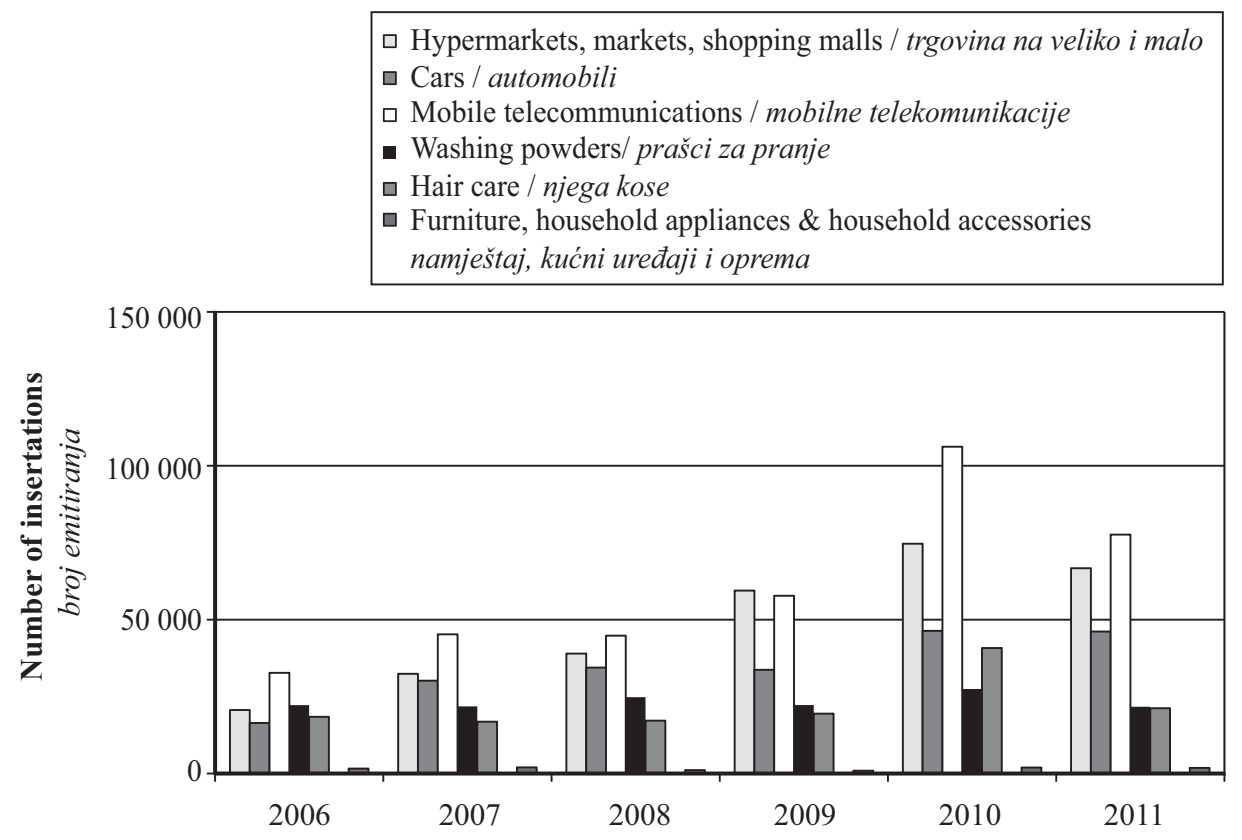

Figure 2 Number of insertations for specific sectors in Slovenia for the period 2006-2011 Slika 2. Broj emitiranja za pojedine sektore u Sloveniji u razdoblju 2006-2011.

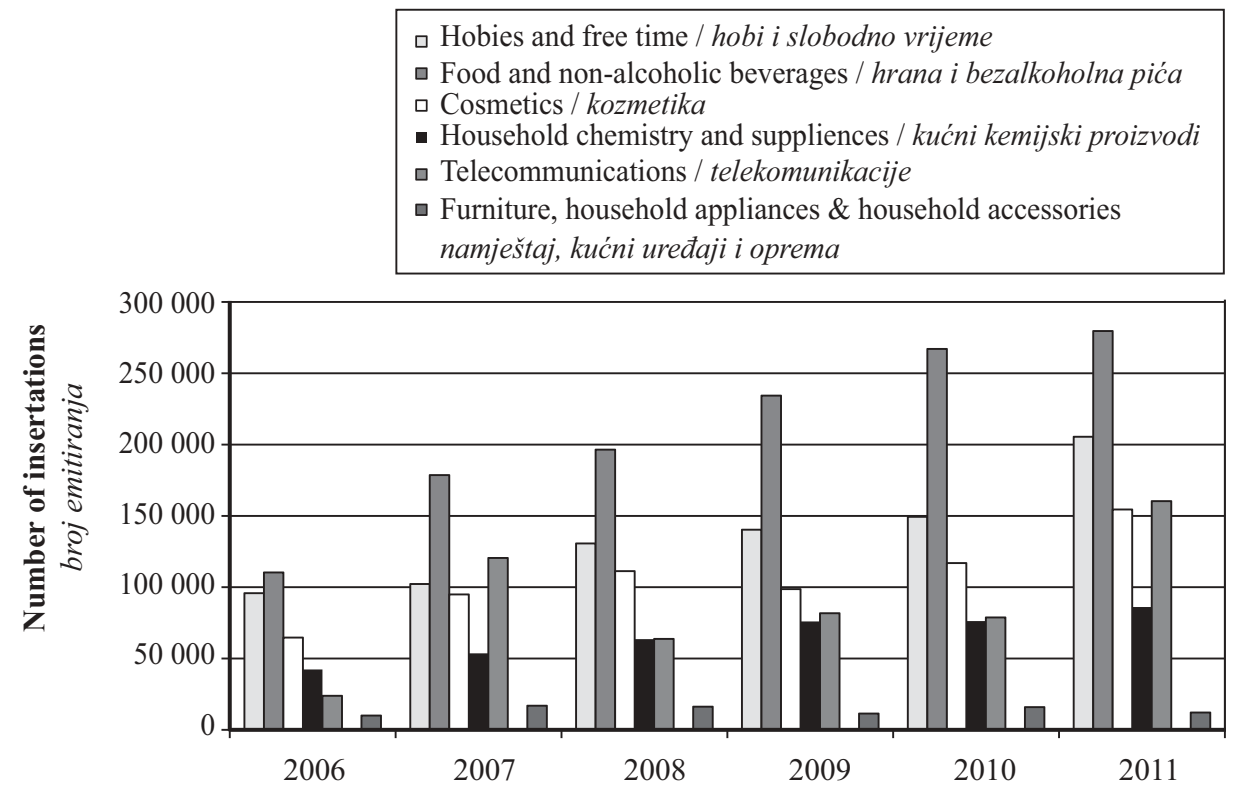

Figure 3 Number of insertations for specific sectors in Serbia for the period 2006-2011

Slika 3. Broj emitiranja za pojedine sektore u Srbiji u razdoblju 2006-2011

and accessories sector was $0.67 \%$ for 2011 to 1.63 for 2008. However, this share is almost constant with small variations in Croatia and Slovenia, while in Serbia it is decreasing significantly every year.

The position of furniture within the furniture, household appliances and accessories sector is much better in Croatia and Serbia than in Slovenia, since in Croatia the share of furniture itself within the sector is between $50.14 \%$ (2011) and (84.75\% (2011), and in Serbia it is between 36.07 (2008) and 73.20 (2010), while the share of furniture within the sector in Slovenia is very low and it ranged between $4.41 \%$ (2011) and $13.92 \%$ (2006). As shown in Figures 4 to 6 , furniture, household appliances and accessories sector consists of different groups in different countries, but it can be compared when rearranged.
Printed media promotion activities are monitored by IPSOS but not based the number of adverts in all Croatian, Slovenian or Serbian printed media, but based on money invested in printed media advertising according to the applicable price list in a particular newspaper or magazine.

Advertising is not monitored by sectors, e.g. on $\mathrm{TV}$, but according to groups of products or production programs. Therefore, the printed media data differs from TV data, but nevertheless the state of promotion activities of wood processing and furniture manufacturing sector can be observed in three countries in question. The following figures show the share of financial investments in printed media promotion by wood processing and furniture manufacturing and the share of some other commonly advertized sectors for comparison. 
........ Jelačić, Oblak, Petrović, Moro, Pirc Barčić, Ćošić, Meloska: Wood Sector Media...

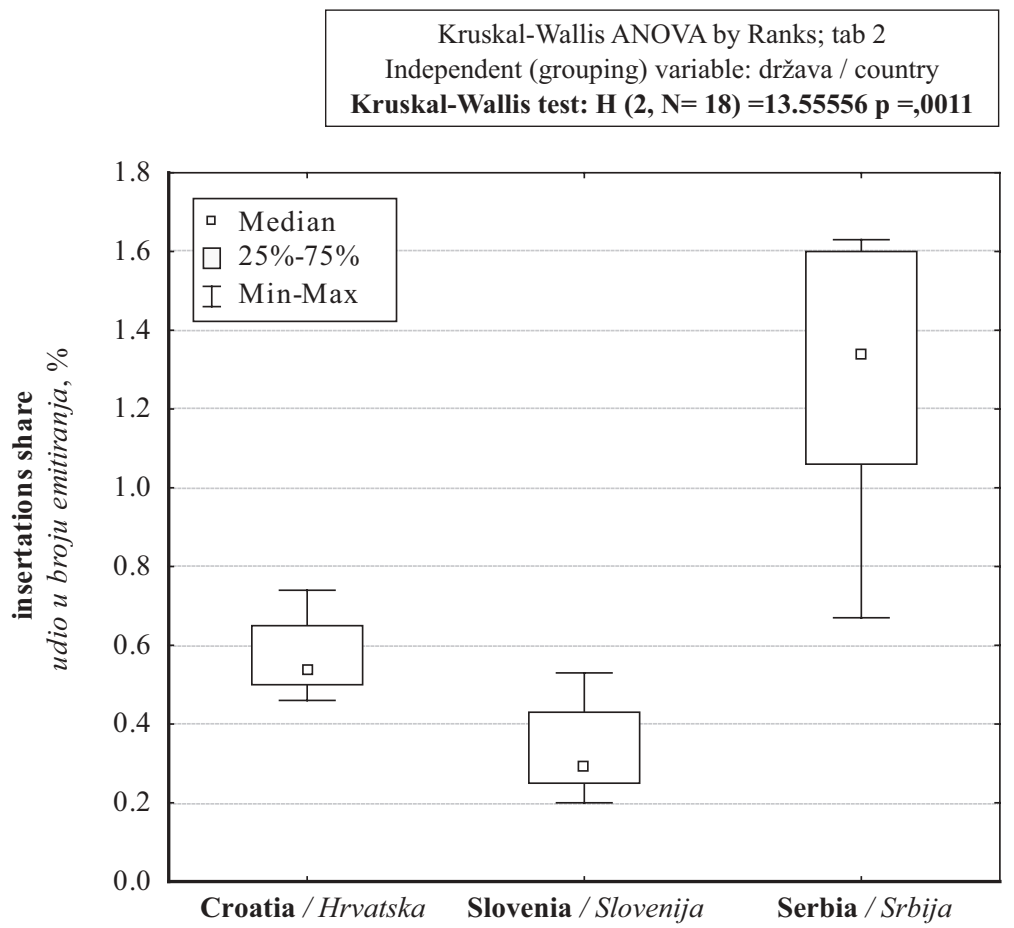

\begin{tabular}{|l|c|c|c|}
\hline \multicolumn{4}{|c|}{ Multiple Comparisons p values (2-tailed); Tab. 2 (Spreadsheet49) Independent (grouping) variable: country / država } \\
& Kruskal-Wallis test: H (2, N=18) $=13,55556 \mathrm{p}=0011$ & Serbia / Srbija \\
\hline & Croatia / Hrvatska & Slovenia / Slovenija & 0.136264 \\
\hline Croatia / Hrvatska & & 0.281045 & 0.000708 \\
\hline Slovenia / Slovenija & 0.281045 & & \\
\hline Serbia / Srbija & 0.136264 & 0.000708 & \\
\hline
\end{tabular}

Figure 4 Comparison of shares of the total number of insertations between Croatia, Slovenia and Serbia Slika 4. Usporedba ukupnog broja emitiranja u Hrvatskoj, Sloveniji i Srbiji

Table 3 Share of furniture within furniture, household appliances and household accessories sector for specific countries in the period 2006-2011 (in \%)

Tablica 3. Udio namještaja u sektoru namještaja, kućnih uređaja i opreme za pojedinu zemlju u razdoblju 2006-2011 (u \%)

\begin{tabular}{|l|c|c|c|c|c|c|}
\hline Country / Država & 2006 & 2007 & 2008 & 2009 & 2010 & 2011 \\
\hline Croatia / Hrvatska & 67.58 & 61.41 & 78.18 & 84.75 & 67.94 & 50.14 \\
\hline Slovenia / Slovenija & 13.92 & 13.76 & 4.74 & 12.97 & 8.85 & 4.41 \\
\hline Serbia / Srbija & 62.69 & 40.75 & 36.07 & 62.59 & 73.20 & 59.47 \\
\hline
\end{tabular}

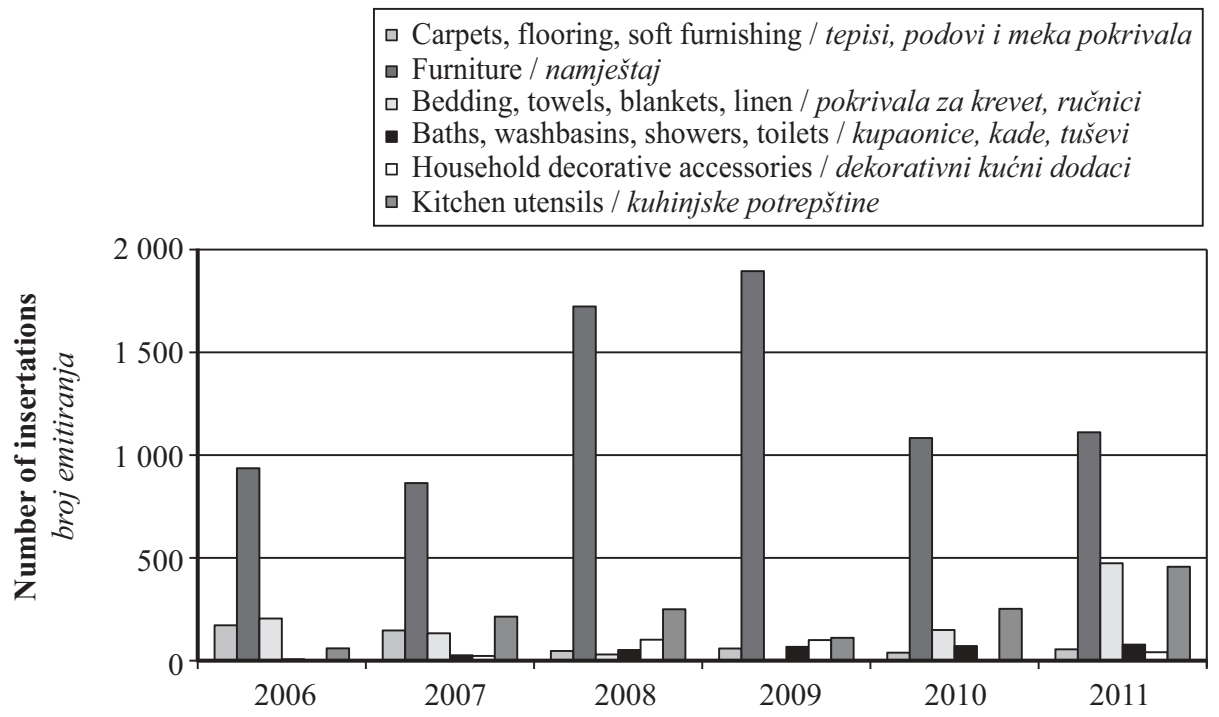

Figure 5 Number of insertations for furniture, household appliances and accessories sector in Croatia for the period 2006-2011 Slika 5. Broj emitiranja u sektoru namještaja, kućnih uređaja i opreme u Hrvatskoj u razdoblju 2006-2011. 


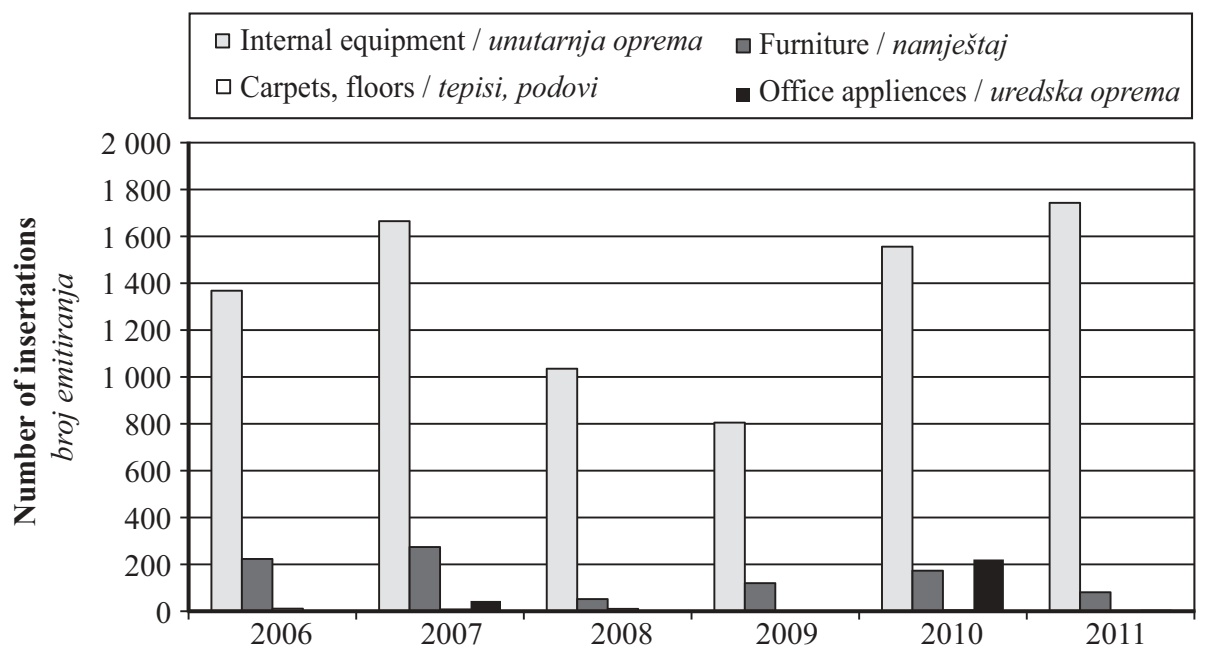

Figure 6 Number of insertations for furniture, household appliances and accessories sector in Slovenia for the period 2006-2011 Slika 6. Broj emitiranja u sektoru namještaja, kućnih uređaja i opreme u Sloveniji u razdoblju 2006-2011.

Figure 11 and Post Hoc test (Tukey HSD test) clearly show that there is a significant difference among investments in printed media promotion in all three countries.

As it can be observed from Figures 8 to 10 and Table 4, the share of furniture manufacturing in the total investment in printed media promotion is much higher than the share of promotion on TV channels. For example, in Croatia, the share of promotion on TV channels was only $0.252 \%$ for furniture and $0.503 \%$ for the sector of furniture, household appliances and household accessories in 2011 (the smallest). The same share of promotion on TV channels was $0.628 \%$ for furniture and $0.741 \%$ for the whole sector in the year 2009 (the highest). At the same time, the share of furniture adverts in printed media was $1.129 \%$ and 1.765 $\%$ for the whole sector in the year 2011 (the smallest), which is much higher than TV promotion. Furniture achieved the highest share in the year 2006 and it was $1.803 \%$, and this share for the whole wood processing and furniture manufacturing sector was $2.825 \%$.

A similar situation has been found in Serbia, where the share of furniture in printed media promotion is higher than in Croatia and it is between $2.50 \%$ in 2011 and $3.28 \%$ in 2009.

In Slovenia, the situation and the share of furniture in printed media promotion is similar to the situation on TV channels. The share of furniture in printed media is between $0.28 \%$ in 2011 and $0.67 \%$ in 2010, and this share is higher than the share on TV channels. As shown, the share of furniture in Slovenia is much lower than shares in Croatia and Serbia.

In terms of total values, Croatian companies invest in printed media promotion much more than companies in Serbia or Slovenia. This could be expected when comparing Croatia and Slovenia, since there are

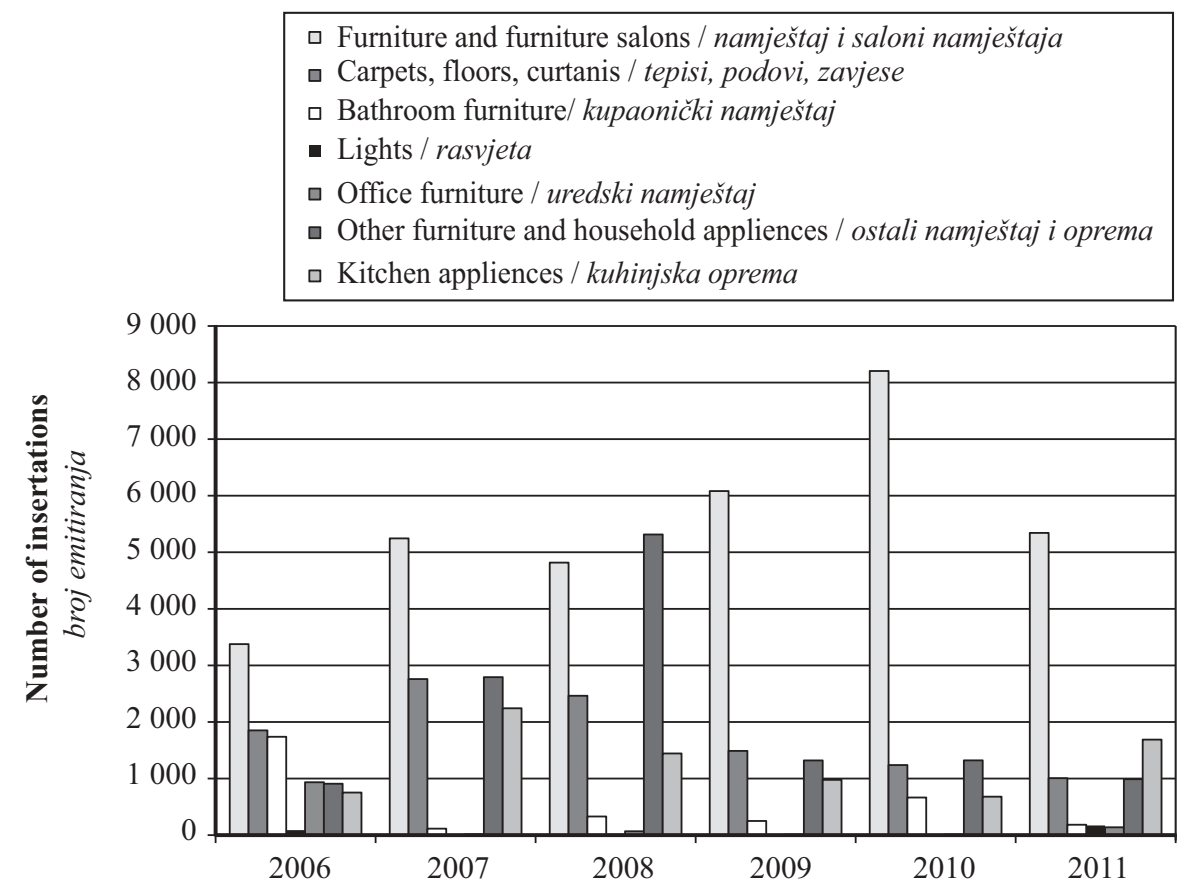

Figure 7 Number of insertations for furniture, household appliances and accessories sector in Serbia for the period 2006-2011 Slika 7. Broj emitiranja u sektoru namještaja, kućnih uređaja i opreme u Srbiji u razdoblju 2006-2011. 

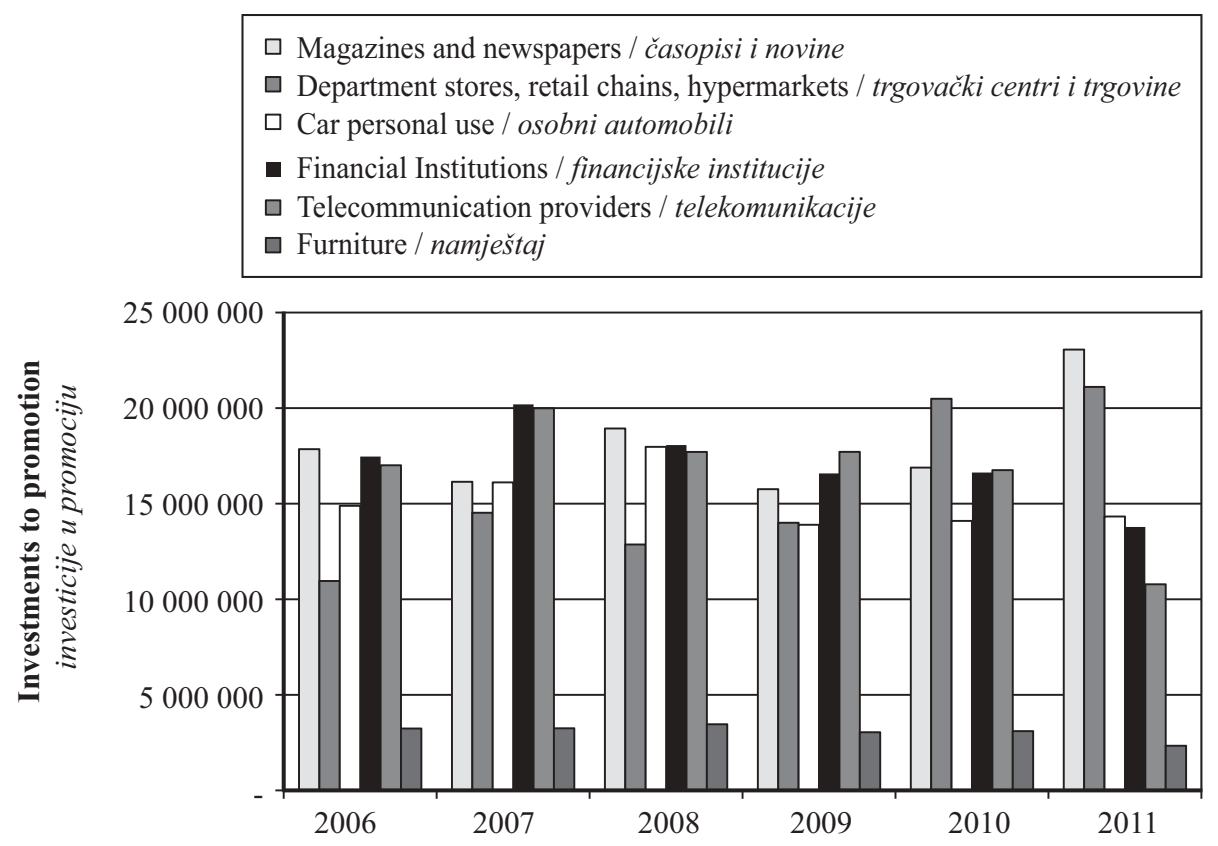

Figure 8 Investments in printed media promotion in Croatia for the period 2006-2011 (in €)

Slika 8. Investicije u promociju u tiskanim medijima u Hrvatskoj u razdoblju 2006-2011. (u EUR)

Table 4 Total investment in printed media promotion (in mil. $€$ ) and share of furniture (in \%) for the period 2006-2011

Tablica 4. Ukupne investicije u promociju u tiskanim medijima (u mil. EUR) i udio izdataka u promociju namještaja (u \%) u razdoblju 2006-2011.

\begin{tabular}{|c|c|c|c|c|c|c|c|c|c|c|c|c|}
\hline \multirow{2}{*}{$\begin{array}{l}\text { Country } \\
\text { Država }\end{array}$} & \multicolumn{2}{|c|}{2006} & \multicolumn{2}{|c|}{2007} & \multicolumn{2}{|c|}{2008} & \multicolumn{2}{|c|}{2009} & \multicolumn{2}{|c|}{2010} & \multicolumn{2}{|c|}{2011} \\
\hline & $\begin{array}{c}\text { Total } \\
\text { invest- } \\
\text { ment } \\
\text { Ukup- } \\
\text { no } \\
\text { inve- } \\
\text { stirano }\end{array}$ & $\begin{array}{c}\text { Share } \\
\text { of } \\
\text { fur- } \\
\text { niture } \\
\text { Udio } \\
\text { namje- } \\
\text { staja }\end{array}$ & $\begin{array}{c}\text { Total } \\
\text { invest- } \\
\text { ment / } \\
\text { Ukupno } \\
\text { investi- } \\
\text { rano }\end{array}$ & $\begin{array}{l}\text { Share } \\
\text { of } \\
\text { fur- } \\
\text { niture } \\
\text { Udio } \\
\text { namje- } \\
\text { štaja }\end{array}$ & $\begin{array}{c}\text { Total } \\
\text { invest- } \\
\text { ment } \\
\text { Ukupno } \\
\text { investi- } \\
\text { rano }\end{array}$ & $\begin{array}{c}\text { Share } \\
\text { of } \\
\text { furni- } \\
\text { ture } \\
\text { Udio } \\
\text { namje- } \\
\text { štaja }\end{array}$ & $\begin{array}{c}\text { Total } \\
\text { invest- } \\
\text { ment } \\
\text { Ukupno } \\
\text { investi- } \\
\text { rano }\end{array}$ & $\begin{array}{l}\text { Share of } \\
\text { furniture } \\
\text { Udio } \\
\text { namje- } \\
\text { štaja }\end{array}$ & $\begin{array}{c}\text { Total } \\
\text { invest- } \\
\text { ment } \\
\text { Ukupno } \\
\text { investi- } \\
\text { rano }\end{array}$ & $\begin{array}{l}\text { Share of } \\
\text { furniture } \\
\text { Udio } \\
\text { namje- } \\
\text { štaja }\end{array}$ & $\begin{array}{c}\text { Total } \\
\text { invest- } \\
\text { ment } \\
\text { Ukup- } \\
\text { no } \\
\text { investi- } \\
\text { rano }\end{array}$ & $\begin{array}{c}\text { Share } \\
\text { of } \\
\text { furni- } \\
\text { ture } \\
\text { Udio } \\
\text { nam- } \\
\text { ještaja }\end{array}$ \\
\hline $\begin{array}{l}\text { Croatia } \\
\text { Hrvatska }\end{array}$ & 179.6 & 1.80 & 204.6 & 1.59 & 216.8 & 1.60 & 194.8 & 1.56 & 204.6 & 1.52 & 206.7 & 1.13 \\
\hline $\begin{array}{l}\text { Slovenia } \\
\text { Slovenija }\end{array}$ & 124.5 & 0.47 & 144.3 & 0.47 & 157.8 & 0.40 & 145.3 & 0.64 & 150.8 & 0.67 & 147.2 & 0.28 \\
\hline $\begin{array}{l}\text { Serbia } \\
\text { Srbija }\end{array}$ & 63.6 & 2.94 & 98.6 & 2.57 & 96.2 & 2.70 & 72.6 & 3.28 & 71.0 & 2.52 & 68.0 & 2.50 \\
\hline
\end{tabular}

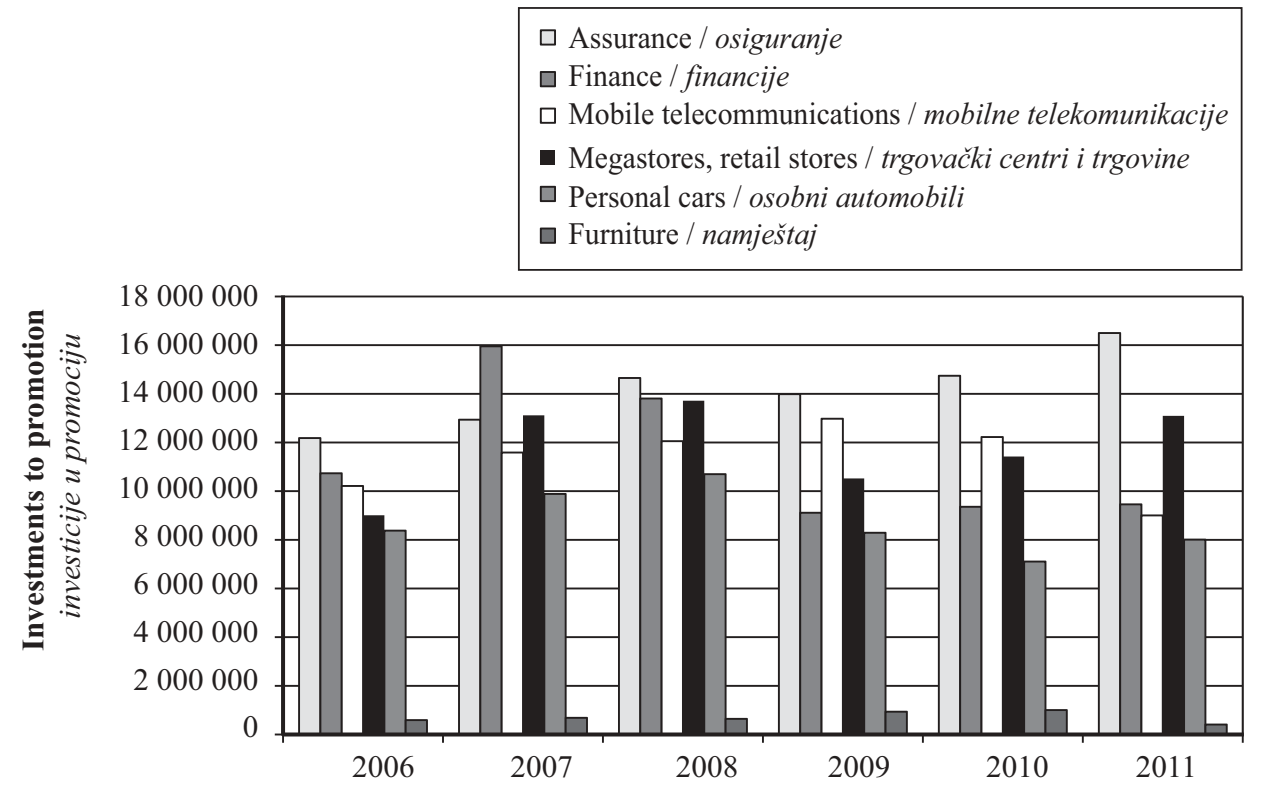

Figure 9 Investments in printed media promotion in Slovenia for the period 2006-2011 (in €)

Slika 9. Investicije u promociju u tiskanim medijima u Sloveniji u razdoblju 2006-2011 (u EUR) 


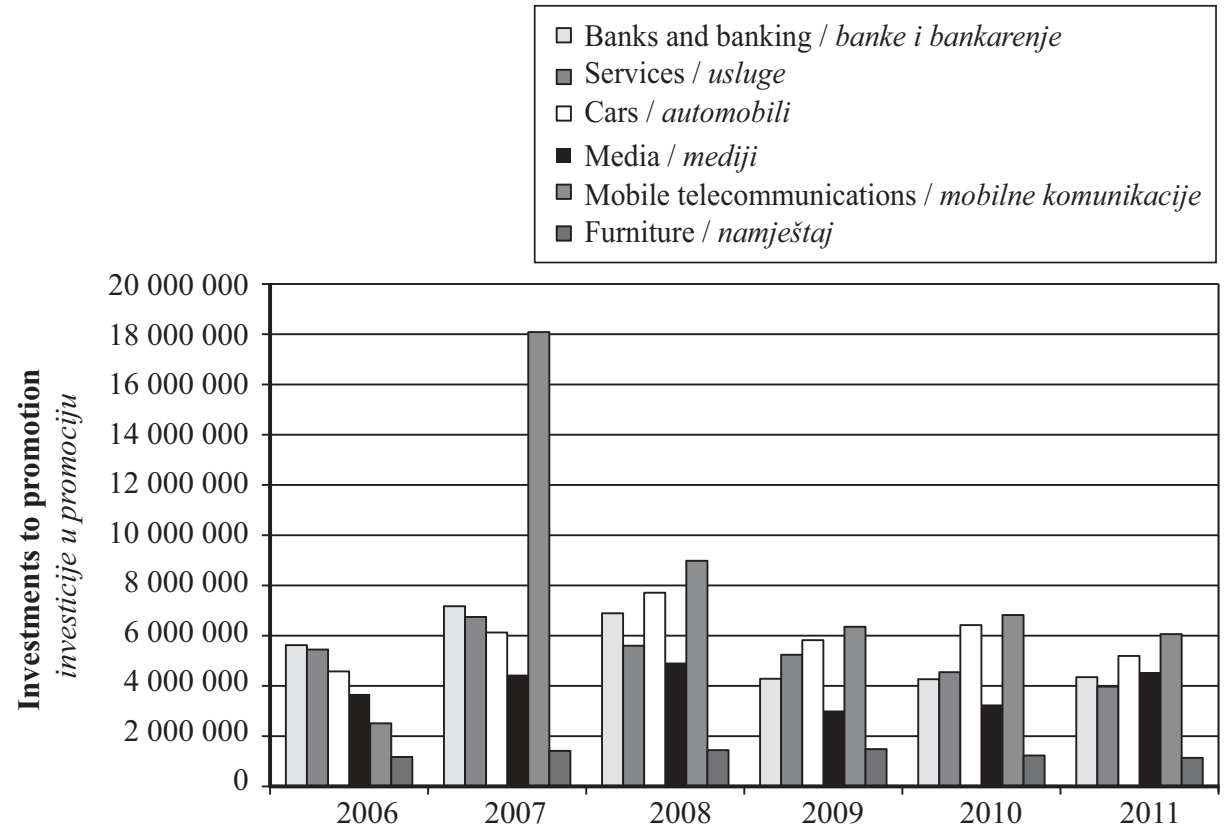

Figure 10 Investments in printed media promotion in Serbia for the period 2006-2011 (in €) Slika 10. Investicije u promociju u tiskanim medijima u Srbiji u razdoblju 2006-2011. (u EUR)
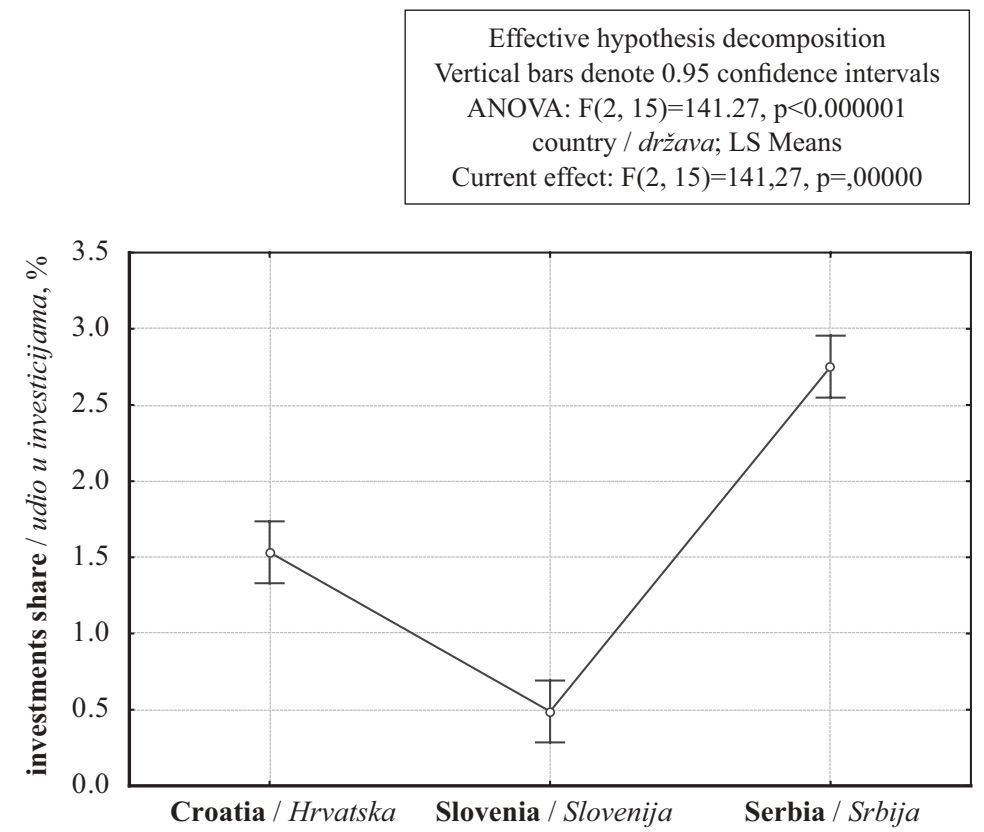

\begin{tabular}{|c|c|c|c|c|}
\hline \multicolumn{4}{|c|}{ Levene's Test for Homogeneity of Variances (Spreadsheet49) Effect: country Degrees of freedom for all F's: 2,15} \\
\hline & $\boldsymbol{M S}$ & $\boldsymbol{M S}$ & $\boldsymbol{F}$ & $\boldsymbol{p}$ \\
\hline tab 4 & 0.027099 & 0.019019 & 1.424862 & 0.271299 \\
\hline
\end{tabular}

\begin{tabular}{|c|c|c|c|c|}
\hline \multicolumn{5}{|c|}{ Tukey HSD test; variable tab 4 (Spreadsheet49) Approximate Probabilities for Post Hoc Tests Error: Between MS $=, 05450, \mathrm{df}=15,000$} \\
\hline & Country / Država & Croatia / Hrvatska & Slovenia / Slovenija & Serbia / Srbija \\
\hline 1 & Croatia / Hrvatska & & 0.000179 & 0.000178 \\
\hline 2 & Slovenia / Slovenija & 0.000179 & & 0.000178 \\
\hline 3 & Serbia / Srbija & 0.000178 & 0.000178 & \\
\hline
\end{tabular}

Figure 11 Comparison of the share of furniture in the total investments in printed media promotion between Croatia, Slovenia and Serbia

Slika 11. Usporedba udjela troškova za promociju namještaja u ukupnim investicijama u promociju u tiskanim medijima u Hrvatskoj, Sloveniji i Srbiji 
more printed publications in Croatia than in Slovenia per capita. The difference between Croatia and Serbia in the total investments in printed media promotion could partly be explained by much lower prices in $€$ for adverts in Serbia, as there should be much more printed publications per capita in Serbia than in Croatia.

\section{CONCLUSION}

4. ZAKLJUČAK

The industrial sector, such as wood processing and furniture manufacturing, obviously deserves a better place in the promotion business of Croatia and Slovenia. This applies especially to TV channels, since there is a saying "if it is not on TV, it doesn't exist". According to the share of wood processing and furniture manufacturing in national GDPs in the countries concerned ( $2 \%$ in Croatia, $1.5 \%$ in Slovenia), the share of this sector in TV promotion $(0.5 \%$ in Croatia, 0.3 $\%$ in Slovenia, $0.6 \%$ in Serbia) is not satisfactory.

The main problem for the promotion of wood products in the Croatian media is the lack of working capital, so wood processing and furniture manufacturing companies decide to invest into something else instead of promotion activities. Another reason is that there is no lobby that would promote wood processing and furniture manufacturing as an environmentally friendly industry. Wooden clusters could and should improve this situation acting jointly in that direction. The battle between wooden clusters and PVC lobby regarding joinery (windows especially) is very hard and PVC is currently winning. However, this should be changed as soon as possible. Another way for companies to improve this situation is to join in a cluster based on production program and not regionally, so as to act together in promotion activities. This would be especially useful with respect to TV promotion, since it is much more expensive than printed media promotion.

\section{REFERENCES}

\section{LITERATURA}

1. AGB Nielsen 2011. Report on the TV promotion for the period 2005-2010. Zagreb.

2. AGB Nielsen 2011. Report on the TV promotion for the period 2005-2010. Ljubljana.
3. AGB Nielsen 2011. Report on the TV promotion for the period 2005-2010. Beograd.

4. IPSOS 2011. Report on the printed media promotion for the period 2006-2011. Zagreb.

5. IPSOS 2011. Report on the printed media promotion for the period 2006-2011. Ljubljana.

6. IPSOS 2011. Report on the printed media promotion for the period 2006-2011. Beograd.

7. Jelačić, D.; Mat'ova, H.; Bičanić, K., 2010: Perception of corporate identity in Croatian and Slovakian wood processing and furniture manufacturing companies, Drvna industrija, vol. 61., No 2/2009, Zagreb, Hrvatska, pp. 103-110.

8. Motik, D.; Jelačić, D., 1997: The analysis of promotional activities in the furniture industry. In: VII Interchair meeting of Organizers and Economists in Wood Industry, XII Economic Forum, State and development trends in wood industry, ISEODI '97, Stubičke Toplice, pgs. 93-98.

9. Stasiak-Betlejewska, R.; Borkowski, S., 2007: Contemporary Developmental Orientations in the Production on the Example of the Furniture Branch. In: Nove trendy v manazerstve kvality. 3 rocnik medzinarodnoho seminara pedagogov studijneho programu Kvalita produkcie. Zbornik prednasok. Trnava, pgs.18-22

10. StatsSoft Inc. (2006.) Statistica, version 7.1. Tulsa, OK, Usa. www.statsoft.com.

11. Šegotić, K.; Motik, D.; Moro, M.; Ojurović, R.; Pirc, A., 2008: Analysis of business success of Croatian wood industry companies. In: IUFRO Unit 4.05.00. International symposium, University of Ljubljana, Slovenia.

12. Troendle, J.F., 1995: A Stepwise Resampling Method of Multiple hypothesis Testing. Journal of the American Statistical Association; 90(429), 370:378.

13. Žujo, M., 2011: Ključ za uspjeh reklame je Facebook. In: Poslovni dnevnik, Večernji list, Zagreb, Croatia, pp. 2425.

\section{Corresponding address:}

Prof. DENIS JELAČIĆ, Ph.D.

University of Zagreb

Faculty of Forestry

Svetošimunska 25

HR-10000 Zagreb,

CROATIA

E-mail: jelacic@sumfak.hr 